\title{
STRATEGIC PLANNING OF SUSTAINABLE DEVELOPMENT OF AGRICULTURE OF LAJKOVAC MUNICIPALITY
}

\author{
Branko Mihailović ${ }^{\text {, Zoran Simonović }}{ }^{2}$, Tomislav Brzaković ${ }^{3}$ \\ *Corresponding authorE-mail: brankomih@neobee.net
}

\begin{tabular}{l} 
A R T I C L E I N F O \\
Original Article \\
Received: 29 September 2017 \\
Accepted: 08 May 2018 \\
doi:10.5937/ekoPolj1802475M \\
UDC 631:502.131.1(497.11 Lajkovac) \\
\hline
\end{tabular}

Keywords:

agriculture, sustainable development, strategic planning, agroindustry, developmental priorities

JEL: O21,Q12,Q15

\begin{abstract}
A B S T R A C T
The paper explores the agricultural potential of the municipality for Lajkovac and accordingly defines the development priorities and strategic measures of sustainable development in this area. The purpose of the research is to examine the real possibilities for the development of agriculture and rural areas of the Municipality. Consequently, the analysis focuses on: the structure of the economy of the Municipality, the importance and role of agriculture and agro-industry in the municipal economy and the development priorities and strategic measures in the agriculture of the municipality. The research's results show that the Municipality of Lajkovac has favorable factor conditions for the development of agriculture. With regard to the development of Lajkovac agriculture in the coming period, it will be important to develop the processing sector, that is, capacity building, especially in the small and medium enterprises in agriculture (SMEA) sector, in the field of processing meat, milk, fruit and vegetables.
\end{abstract}

(C) 2018 EA. All rights reserved.

\section{Introduction}

To organize business environment for agricultural producers, companies, associations and other interested actors, in fact, it means organizing individual institutions, their relations on market principles, to arrange all these relations in a consistent system. The condition for this is to organize the functions of the state in a modern way, in terms of an incentive, development-oriented factor of the economy. It should be not that the macroeconomic environment is a composition that functions as consistent

1 Branko Mihailović, Ph.D., Senior Research Associate, Institute of Agricultural Economics, Volgina Street no. 15, 11060 Belgrade, Serbia, Phone: +381 1169728 58, E-mail: brankomih@neobee.net, ORCID ID (https://orcid.org/0000-0002-2398-6568)

2 Zoran Simonović, Ph.D., Scientific Associate, Institute of Agricultural Economics, Volgina Street no. 15, 11060 Belgrade, Serbia, Phone:+381 1169728 58, E-mail: zoki@medianis. net ORCID ID (https://orcid.org/0000-0002-2769-6867)

3 Tomislav Brzaković, Ph.D., Faculty of Applied Management, Economics and Finance, Jevrejska Street no. 24, 11000 Belgrade, Phone: +381 11264 3390, E-mail: tomislavbrzakovicmef@gmail.com, ORCID ID (https://orcid.org/0000-0001-9187-7251) 
interactions between individuals and institutions. In that whole, individuals with new rights and obligations need to function, with their new own image. The same is true of all institutions that, with new rules, must have individuals and groups with clearly defined roles.

The Serbia has great potential for the agricultural sector, which is not fully exploited (Simonović et al., 2012). With adequate strategic planning, agriculture can make a significant contribution to the economic development of the country. Because of its connection and influence on other sectors, it is extremely important to the development of Serbia, since it employs, directly or indirectly, a large number of people, participates in a significant part in the external trade, provides nutritional safety of citizens, contributes to rural development and ecological balance. The achievement of agrarian competitiveness requires macroeconomic management to change the basic elements of agricultural development strategies, first of all, towards the creation of sustainable agricultural systems, whose growth is driven by knowledge and innovation, as well as in the direction of market development and agricultural product chains. This is the only reason that agriculture is one of the most important economic activities in Serbia, and is a backbone of economic growth and development (Vojinović et al., 2017).

The municipality of Lajkovac, located in the region of Western Serbia, in the middle part of the Kolubara valley, is the rural municipality of high social responsibility towards sustainable rural development and preservation and improvement of the quality of the environment (Strategy for development of agriculture and rural development of Lajkovac in the period 2011-2015). The municipality has an attractive economic and social environment for the life, work and new employment of the population, as well as the business of business entities, and develops its stimulating business and social climate based on high investments in the development of institutions, infrastructure, human resources, knowledge, innovation and "clean "Technology.

The municipality is cultivating traditional values, continuously strengthening interinstitutional, interregional and inter-ethnic cooperation, contributing to balanced economic and social development and balanced regional development of the Republic, and enabling all inhabitants to have a lot of inclusion in the social and economic life of the community (Development Strategy for Agriculture and Rural Development Lajkovac 2011-2015).

When defining the priorities to the local level, the following documents need to be thoroughly consulted and refer to certain segments of documents depending on which of the listed sectors are appropriate. These include (Mihailović et al., 2007): 1. Serbia's National Strategy for Serbia's Accession to the European Union; 2.Serbia's Action Plan for Implementation of Priorities of the European Partnership; 3.Poverty Reduction Strategy; 4.Resource strategies; 5.Joint Program Document for Neighboring Programs; 6. Action plans for the Government of Serbia and 7. Policies of individual levels. Also, all local development plans that already exist or are being drafted should also be taken. Special attention should be paid to the overall goal during the development of 
local development plans. The general goal should be defined at the level at which it is possible to check whether the envisaged changes and improvements occur and whether the desired situation is closer than in the definition period. Each local community should see and perceive its real possibilities and capabilities in the realization of the planned general goal. The mistakes that most commonly appear when defining the general goal are related to the over-expressing of the general goal. The general objective should be defined so that it includes the following principles (Mihailović et al., 2007): to contribute to the achievement of the overall strategic priorities of the Republic of Serbia; Not to be too general in character or too ambitious; To be expressed by pointing to the target groups and being expressed as the desired changed state, not as a process.

There are many types of strategies and a wide repertoire of strategic options on the field of agriculture and the food industry. It is important that the process of selecting the strategy is appropriate to the very nature of the strategic situation. In order to define a strategic situation, it is primarily important to deal with the analysis of the business environment and resources. The purpose of the analysis is to identify possible chances and hazards and thus create a basis of directing effort. Defining a strategic situation is part of a conceptual framework that shows the relationship between a strategic situation, a strategic focus, and a strategic option. When defining a strategic situation, we must analyze the environment and resources in agriculture. The environment can be: general and targeted, favorable and unfavorable, good and bad, urgent, delayed and permanent. Also, the impact on agricultural production can be negative, positive and stabilizing.

Today we see sustainable development through the ability to improve the quality of life and its maintenance for future generations arising from three basic factors: environment, economics and societies. Developed industrial countries place "health and knowledge" at the very top of their development priorities and define this as the essence of the quality of human life (Mihailović et al., 2007). Despite its widespread use, sustainability is a term used and interpreted in various ways (Dobson, 1996). For a long time, the concept of sustainability has largely remained a synonym for the sustainability of the human environment. Recently, it has been expanded not only to consider the environment, but also to economic and social development (Elkington, 1998). This extension of the concept of sustainability was created primarily because it is not only impractical, and sometimes even impossible, to analyze the sustainability of the natural environment without considering the social and economic aspects of relevant social communities and their activities.

Another argument for the continuation of this consideration is that if capital should be extended to future generations, then it is logical that it should also be extended to all of the present generation. Therefore, one of the primary goals set by the World Commission for Environment and Development is the eradication of world poverty and inequality. As noted, the sustainability of agriculture can be viewed through three components: ecological, economic and social. This points to the following definition: "Sustainability refers to the long-term maintenance of the system in accordance with the human environment, economic and social development" (Đuričin, 2006). Although http://ea.bg.ac.rs 
this definition serves to determine the basic content of the concept of sustainability, it is obvious that sustainability as a phenomenon represents a specific goal to be achieved. The design of sustainable development as the goal of the business activity of the company is most fully expressed through the term "triple bottom line." The "triple bottom line" is a term that was formulated and strongly advocated by John Elkington, director of the Consulting Company for strategy of sustainability and author of numerous influential books on the corporate environment. His view of this concept is based on the idea that business does not only relate to one goal that is reflected of maximizing economic value, but has added an expanded set of goals that involves the involvement of the environment and the wider community.

\section{Materials and methods}

In order about accomplish the research task, all available sources of information will be used: 1) Official local statistics, i.e. The data onto the Republic Bureau of Statistics; 2) National and municipal strategies and development documents from a specific area; 3) Materials of the Serbian Chamber of Commerce and other domestic institutions and organizations; 4) Research of domestic and foreign authors in the thematic field; 6) Research carried out by the Institute of Agricultural Economics and its associates in the previous period.

In the realization of the research task, which refers to the assessment of agricultural potentials and defining the development priorities to the municipality of Lajkovac, the analysis of secondary data will be used (the Agricultural Census from 2012, etc.), spatial analysis of the relevant variables, as well as research based on focus groups made up of Stakeholders interested in the agriculture and food industry of the municipality of Lajkovac.

Also, a valuable support for the diagnosis of the condition in this area will be a "SWOT" analysis, based on which the development priorities and strategic directions of action will be formulated. By combining these methods of research, a more reliable answer to key issues arising from the analysis of agriculture, food industry and development priorities of the municipality of Lajkovac can be obtained.

\section{Results}

Given that the Gross Value Added (GVA) and Gross Domestic Product (GDP) statistics are not available at the JLS level (Local Self-Government Unit), the structure of GVA by activity for the level of the Kolubara region is given below (Table 1). 
Table 1. Gross value added by activity in the Kolubara region, 2013.

\begin{tabular}{|l|c|c|}
\hline \multicolumn{1}{|c|}{ Activity } & $\begin{array}{c}\text { Value, mil. } \\
\text { RSD }\end{array}$ & Structure, \% \\
\hline Agriculture, forestry and fisheries & 11,170 & 20.07 \\
\hline $\begin{array}{l}\text { Mining, manufacturing, electricity, gas and steam supply, water supply and } \\
\text { waste water management }\end{array}$ & 15,509 & 27.87 \\
\hline Construction & 2,024 & 3.64 \\
\hline $\begin{array}{l}\text { Wholesale and retail trade and repair of motor vehicles, transport and } \\
\text { storage, accommodation and food service }\end{array}$ & 8,534 & 15.34 \\
\hline Information and communication & 516 & 0.93 \\
\hline Financial and insurance activities & 562 & 1.01 \\
\hline Real estate business & 6,098 & 10.96 \\
\hline $\begin{array}{l}\text { Professional, scientific, innovation and technical activities; } \\
\text { Administrative and support service activities }\end{array}$ & 1,234 & 2.22 \\
\hline $\begin{array}{l}\text { State administration and compulsory social security, education, health and } \\
\text { social protection }\end{array}$ & 9,156 & 16.45 \\
\hline Arts, entertainment and recreation and other service activities & 840 & 1.51 \\
\hline In total & 55,643 & 100.00 \\
\hline
\end{tabular}

Source: Statistical Yearbook of the Republic of Serbia, 2015

Note: GVA (Gross value added) is obtained as the difference between the value of production and intermediate consumption

The structure of gross value added by activities shows that according to this indicator in the Kolubara region dominate: 1) Mining, manufacturing, electricity, gas and steam to supply, water supply and waste water management (27,87\%) and 2) Agriculture, forestry and the structure of the economy for the level of the municipality of Lajkovac was obtained through the employment indicators (Table 2) and based on the market analysis of the most important enterprises in the economy.

Table 2. Economically active population engaged in activity in Lajkovac, 2011.

\begin{tabular}{|l|c|c|}
\hline \multicolumn{1}{|c|}{ Activity } & $\begin{array}{c}\text { Employee } \\
\text { number }\end{array}$ & Structure (\%) \\
\hline Agriculture, forestry and fisheries & 2,006 & 30.18 \\
\hline Mining & 1,311 & 19.72 \\
\hline Manufacturing industry & 734 & 11.04 \\
\hline Electricity, gas, steam and air conditioning supply & 136 & 2.05 \\
\hline $\begin{array}{l}\text { Water supply; waste water management control of the waste removal } \\
\text { process and the like }\end{array}$ & 87 & 1.31 \\
\hline Construction & 285 & 4.29 \\
\hline $\begin{array}{l}\text { Wholesale and market. on a little; repair of motor vehicles and } \\
\text { motorcycles }\end{array}$ & 367 & 5.52 \\
\hline Traffic and storage & 367 & 5.52 \\
\hline Accommodation and food services & 83 & 1.25 \\
\hline Information and communication & 40 & 0.60 \\
\hline Financial and insurance activities & 28 & 0.42 \\
\hline Real estate & 1 & 0.02 \\
\hline
\end{tabular}




\begin{tabular}{|l|c|c|}
\hline \multicolumn{1}{|c|}{ Activity } & $\begin{array}{c}\text { Employee } \\
\text { number }\end{array}$ & Structure (\%) \\
\hline Professional, scientific, innovation and technical activities & 56 & 0.84 \\
\hline Administrative and support service activities & 353 & 5.31 \\
\hline State Administration and Defense; compulsory social security & 315 & 4.74 \\
\hline Education & 230 & 3.46 \\
\hline Health and social work & 161 & 2.42 \\
\hline Art; entertainment and recreation & 31 & 0.47 \\
\hline Other service activities & 47 & 0.71 \\
\hline $\begin{array}{l}\text { Household activity as an employer; activity of households producing } \\
\text { goods and services for their own use }\end{array}$ & - & 0.00 \\
\hline Activities of extraterritorial organizations and bodies & 1 & 0.02 \\
\hline Unknown & 8 & 0.12 \\
\hline In total & 6,647 & 100.00 \\
\hline
\end{tabular}

Source: Census of Population, Households and Dwellings in the Republic of Serbia, 2011

According to the Census of Population, Households and Housing 2011 in the structure of the economically active population engaged in occupation in Lajkovac, the largest percentage of the population is engaged in (Table 2):

- agriculture (30.18\%);

- mining (19.72\%);

- manufacturing industry (11.04\%).

In the structure of the Lajkovacindustrial economy, the dominant sector is dominated by the individual sector (http://skgo.org/municipalities/16/privreda). Important are the following: agriculture, livestock, vegetable and fruit growing. According to the data onto the Department of Economy and Property Legal Affairs of the municipality of Lajkovac, there are two industrial zones. One is on the surface of 104.5 ha at the entrance to Lajkovac (privately owned land with infrastructure, here is "Vindija", "Dairy MO", silo), and the second zone (industrial zone 2, area of 149.7 ha In KO Nepričava) will be built along the highway, at the end of the road (Corridor 11). The main goal of creating a new industrial zone is attracting investors and assigning purposes of unearned land in accordance with their requirements and needs, which is a valuable asset for Greenfield investments. Environmental practice shows that greenfield investment has had an impact on economic growth, since this form of investment, apart from directly (increasing employment, exports, taxes paid by the state) indirectly affected their economic development - the arrival of Greenfield creates subcontracting chains and develops small And Medium Enterprises (Report on Strategic Environmental Impact Assessment of Detailed Regulation Plan, Industrial Zone 2, Lajkovac, 2014). This approach is justifiable since the key constraints of the local economy are: low level of economic activity, lack of market, underdevelopment of the private sector, entrepreneurship, management and marketing skills (Local sustainable development strategy of the municipality of Lajkovac for the period 2015-2025). 
For the purpose of a more detailed introduction to the economic structure in the municipality of Lajkovac, the following companies are listed:

- Elmont-drive RB "Kolubara". The company was founded in 1969. A small electro-machine, assembly and production company, which was founded by eight workers. As an independent business until 1983. Then it is part of the then SOUR REIK "Kolubara" in Lazarevac, more precisely in "Kolubara Metal", and since 1990 in EPS. Today, the Elmont plant is organized in four work units: "Energy", "Telecommunications", "Metal Plant" and "Maintenance".

- EPS RB "Kolubara" - Surface mine "Tamnava - Zapadnopolje" gave the highest amount of coal in the system of the Mining Basin "Kolubara". Annually, out of a total of 29, about 14 million tons of lignite are produced in this coal mine. So it was before the flood, and it is expected that this figure will be re-established this year;

- - "Vindija" d.o.o., Lajkovac. Vindia's business headquarters in Serbia is located in Lajkovac and unites the factory of poultry meat products of the Vojvodina Plandiste opened with May 2009. In installations covering an area of 7,000 $\mathrm{m}^{2}$, more than 200 workers are employed, the majority of local residents. The high quality of products coming from Plandište was confirmed by obtaining an export control number for export of goods to the European Union (http://www.vindija.hr);

- Dairy MO, Lajkovac. It is located in the very town of Lajkovac. The company's production program includes milk and dairy products. The most prevalent products are: yoghurt, pasteurized milk and hard cheese;

- Fruvlader for fruits "Fruvela" d.o.o. was founded in 2006. There is a cold storage in Serbia and this part of Europe. The main activities of the refrigerator are the processing, purchase, export and freezing of fruits. The main products are: strawberry, raspberry, blackberry, cherry, plum and apricot in various forms. Production of Fruvel refrigerator is based on ISO 9001: 2008 and HACCP standards. At the same time, strawberries, raspberries, cherries, plums and apricots are exported from the Fruvela refrigerator to EU countries.(http://www.fruvela.com);

- BorverkEurotrade. The area of activity of the company is the production of packaging materials from plastic masses, that is, the company is engaged in the production and sale of five preforms and bottles, from which the blowing gets the bottles of the desired shapes. Patented production and technology guarantee high quality preforms and bottles of various sizes, colors and sizes. (Http://www.borverk.rs);

- Iva Agrard.o.o. Lajkovac. This Comapany exists on more than 15 years and employs up to 50 workers. The leading producer of substrates for cultivating plants "Magic Land", is the leader in the production of building stone and all types of stone agreras in the quarry OSTRES̆, and since 2008 the IVA GIFT SHOP (www. iva-agrar.rs) was opened with the company; 
- "MikroElektronika" is engaged in the production of software and hardware tools for microcontrollers. As pioneers in Serbia, they have written and published numerous books in this field, and among their clients, they are even "Sony", "Hitachi" and many others (http://www.mikroe.com);

- "Sanikomerc" is a family company with a tradition of over twenty years, based in Lajkovac. Products of carton transport packaging, more precisely "American boxes". There are 1,300 products in the assortment, have capacities and opportunities to respond to the requirements of the European market. Currently, they work with thirteen employees;

- "Borverk" d.o.o. Lajkovac is a company for production, trade and import-export, established in 1990. Borverk is in the status of an active company. The main activity of the company is the exploitation of building and decorative stone (https:// borverk.ls.rs/rs);

- "Nodel" is an enterprise for marketing, engineering, manufacturing, marketing and post-marketing services, doo Lajkovac. The company was founded in 1997. The main activity of the company is the production of knitted and crocheted socks.

In the Municipality of Lajkovac there are opportunities for development of service activities, among which are particularly deficient personal services, individual craft services, information and project services, marketing services, various consulting and business services to the SME sector, trade services, hotel and catering services, services in the agricultural sector And other activities (Local Sustainable Development Strategy of the Municipality of Lajkovac for the period 2015-2025).

In the following period, the improvement in the economic structure of the municipality of Lajkovac can be accelerated by the inflow of funds of investments in new enterprises and the recapitalization of existing ones. Also, infrastructure facilities for industrial zones as well as local facilities and incentives will be significant for further growth and development of the entire economy in the territory of the municipality of Lajkovac.

Importance and role of agriculture and agro-industry in the municipal economy. Participation in gross value added (GVA) of agriculture in the gross domestic product (GDP) of the Republic of Serbia in the period 2007-2014. The average annual amount is $6.6 \%$ (Economic accounts of agriculture in the Republic of Serbia 2007-2014).

Importance and contribution of agriculture the GDP of Serbia is especially high when the activities of agriculture, the contribution and value are created in the food industry, the production of beverages and tobacco. However, the export of agrarian farmers is dominated by primary agricultural products and products of low added value (Serbian Chamber of Commerce, 2016).

Given that the SBS does not have economic accounts of agriculture at the level of the region, the area and the local self-government unit (Local Self-Government Unit), The point of the municipality of Lajkovac is analyzed through indicators of employment, 
factor conditions for the development of agriculture, companies operating in the agricultural food sector, etc.

The participation in active farmers (economically active population in the sector A, "Agriculture, forestry and fishery") in the total economically active population that is engaged in the occupation in the municipality of Lajkovac amounts of $30.18 \%$, which is more in comparison with the republican level $(14.8 \%$, But still lower than the level of participation in the Kolubara region of $40.06 \%$ (Table 3 ).

According to the data onto the Department of Economy and Property Legal Affairs of the Municipality of Lajkovac, a large number of employees in the Kolubara Mining Basin and migration of young people for education and work engagement have resulted in a small number of farms mainly engaged in agriculture. Consequently, there are no large, marketoriented agricultural holdings, nor intensive agriculture.

Table 3. Number of active farmers in the Kolubara region and the municipality of Lajkovac, 2011

\begin{tabular}{|l|c|c|c|}
\hline & $\begin{array}{c}\text { Economically active } \\
\text { population }\end{array}$ & $\begin{array}{c}\text { Number of active } \\
\text { farmers }\end{array}$ & $\begin{array}{c}\text { Participation of active farmers in } \\
\text { economically active population } \\
\text { (\%) }\end{array}$ \\
\hline Republic of Serbia & $2,304,628$ & 340,186 & 14.8 \\
\hline Kolubara district & 72,899 & 29,200 & 40.06 \\
\hline Valjevo & 35,500 & 9,605 & 27.06 \\
\hline Lajkovac & 6,647 & 2,006 & 30.18 \\
\hline Ljig & 5,902 & 2,929 & 42.63 \\
\hline Mionica & 6,339 & 3,594 & 56.70 \\
\hline Osecina & 6,058 & 4,327 & 71.43 \\
\hline Ub & 12,453 & 6,739 & 54.12 \\
\hline
\end{tabular}

Source: Census of Population, Households and Flats in Serbia 2011 (Economically active population engaged in activity by activity)

The municipality of Lajkovac has favorable factor conditions for the development of agriculture. The favorable climatic factors, the diversity of the types of land, favorable hydrogeology and good road infrastructure are good conditions for the development of agricultural production, and above all, livestock, forestry and fruit growing (Local Lajkovac Development Strategy for the period 2015-2025).

Plant production, fruit and wine production do not take a significant place, although favorable conditions exist on this (Agricultural List, 2012). The municipality of Lajkovac has a significant tradition in livestock production, especially when it comes to cattle breeding.

Lajkovac, a traditional exhibition of breeding cows and heifers of the Simmental race, is being known, which has been holding and gathering in Lajkovac high quality Simmental throats, not only from the municipality of Lajkovac, but also from neighboring municipalities (Local Sustainable Development Strategy of the Municipality of Lajkovac for the period 2015-2025.). 
Primary agricultural production is dominant in the sector of family farms. According to the Census of Agriculture in 2012, registered breed farms is 1,516, and the total number of agricultural holdings is 2,578. The utilized agricultural land (KPZ) is 10.291 ha and its share in the total area of JLS is 55\%. The average size of the land (KPZ) per farm is 3.99 ha. Namely, the municipality is dominated by small, non-specialized agricultural producers without clear business and market orientation. The result of such a production structure and poor governance are low and irregular income with the absence of serious planning, development and major investments (Program of Measures for Support for Implementation of Agricultural Policy and Rural Development Policy for the Municipality of Lajkovac in 2016). According to the data onto the Department of Economy and Property Legal Affairs of the Municipality of Lajkovac (Report for the Focus Group meeting in the premises of the municipality of Lajkovac, 2016):

- $\quad$ Farming is represented only for crops that serve as animal feed, which means that valorization is done through livestock breeding;

- Vegetation is not developed;

- $\quad$ Orchards have plenty of farmers, but there are no large, modern orchards, or fruit market production. In the production of brandy, the most common plum is, and in the town of Bajevac there is one plantation of blueberries;

- Cattle breeding's in decline, with only a few larger farms in cattle production (fodder cattle, dairy farms) in Vračević, Strmovo, Pepeljevac (in this place there is also a larger farm of pigs of about 800 fattening animals), Stepanje, Bajevac;

- Vindija from Varaždin has a farm for fattening broilers in the town of Rubribreza, and in Lajkovac (Varos) there is a central and distribution center;

- Poultry is not significantly developed with the arrival of Vindija. There is no cooperation between Vindija and family farms. There are two larger broiler farms in the agricultural holdings sector;

- There is interest in sheep breeding and beekeeping, and the goat is poorly developed;

- $\quad$ There are no interested agricultural producers for organic production.

In the processing of agricultural products, a smaller number of subjects in the SME sector is registered: Processing of poultry meat ("Vindija" doo, Lajkovac); Cereal (mill of the company "Agraria Campo"); Milk ("Dairy MO", Lajkovac); Fruit (Fruvela Fruit); Production of substrates for cultivation of plants ("Iva Agrar" doo Lajkovac). With regard to the development of Lajkovac agriculture in the coming period, it will be important to develop the processing sector, that is, capacity building, especially in the MESP sector, in the field of processing meat, milk, fruit and vegetables. It will also be important to invest in plants for sorting, packaging and standardization of fruits and vegetables, as well as in the processes of implementation and certification of food safety and quality systems. 


\section{Discussions}

Each local development initiative must take into account that the territory is a system or a set of complex elements that act on the basis of their own complex nature and properties (Mihailović et al., 2007). It can not be denied that the imposition of external (alien) development models often contributes to the banalization of those territories that have been the subject of such models. Each local self-government should itself to find the best modality for making its own plan. The essence of the local agricultural development plan should be seen in obtaining a document that is based on integrity and integrity in order to obtain a genuine decision-making process.

The applied measures and activities aimed at overcoming the unfavorable situation in this sector did not yield the desired results (Nikolic et al., 2017). Consequently, when defining a strategy, there should be three key elements: participation of the population and local authorities, social consensus, sustainability. The overall objective of local agricultural development should be directed towards improving the material and social status of the local population, promoting an integral rural development model based on linking rural with the city economy and diversifying economic activities in the countryside. Consequently, the following results should be expected: increasing competitiveness, more complete use of all resources, harmonizing agricultural production, increasing employment and income of the population. Achieving these results requires the real creation of a "SWOT" matrix (Table 4).

The optimal strategy for the development of agriculture and food industry in the municipality of Lajkovac in the "SWOT" environment is a mini - maxi strategy that implies minimizing weaknesses and threats and at the same time maximizing power and chances in the environment such as regional integration, education and advisory services in agribusiness and etc. Agriculture provides food security for the population, but it is also the main source of raw materials for numerous industrial capacities (Vasiljević et al., 2011). Consequently, the strategic objective of the municipality of Lajkovac in the field of agriculture and rural development is to strengthen the competitiveness of developmentally oriented agricultural holdings, protect and preserve the environment and cultural and historical values, as well as to improve the living standards and conditions for employment and the life of the rural population (Development Strategy for Agriculture and Rural Development Lajkovac period 2011 - 2015). 
Table 4. SWOT matrix of agriculture and rural development of the municipality of Lajkovac

\begin{tabular}{|c|c|}
\hline STRENGTHS & WEAKNESSES \\
\hline $\begin{array}{l}\text { - In Lajkovac municipality there are opportunities } \\
\text { for development of service activities, among } \\
\text { which are particularly deficient personal services, } \\
\text { individual craft services, information and project } \\
\text { services, marketing services, various consulting } \\
\text { and business services to the SME sector, trade } \\
\text { services, catering and hotel services, services in } \\
\text { the sector Agriculture and other activities. } \\
\text { - The participation IN active farmers in the total } \\
\text { economically active population that occupies } \\
\text { the profession in Lajkovac amounts to } 30.18 \% \text {, } \\
\text { which is more in comparison with the republican } \\
\text { level (14.8\%). } \\
\text { - The Municipality of Lajkovac has favorable } \\
\text { factor conditions for the development of } \\
\text { agriculture. Favorable climatic factors, diversity } \\
\text { of soil types, favorable hydrogeology and good } \\
\text { road infrastructure are good conditions for the } \\
\text { development of agricultural production, and } \\
\text { above all, animal husbandry, agriculture and fruit } \\
\text { growing. } \\
\text { - The Municipality of Lajkovac has a significant } \\
\text { tradition in livestock production, especially when } \\
\text { it comes to cattle breeding. } \\
\text { - Lajkovac, a traditional exhibition of breeding } \\
\text { cows and heifers of the Simmental race, is } \\
\text { known, which has been holding and gathering } \\
\text { in Lajkovac high quality Simmental throats, not } \\
\text { only from the municipality of Lajkovac, but also } \\
\text { from neighboring municipalities. }\end{array}$ & $\begin{array}{l}\text { - The municipality is dominated by small, non- } \\
\text { specialized agricultural producers without clear } \\
\text { business and market orientation. } \\
\text { - The result of the production structure and poor } \\
\text { governance are low and irregular income with the } \\
\text { absence of serious planning, development and } \\
\text { greater investment. } \\
\text { - Undeveloped processing of agricultural products } \\
\text { on family farms and the MESP sector. } \\
\text { - A large number of employees in the Kolubara } \\
\text { Mining Basin and migration of young people for } \\
\text { education and work engagement have resulted } \\
\text { in a small number of farms mainly engaged in } \\
\text { agriculture. } \\
\text { - There are no large, market-oriented agricultural } \\
\text { holdings, nor intensive agriculture. } \\
\text { - In the structure of plant production, fruit and } \\
\text { vineyards do not occupy a significant place, } \\
\text { although favorable conditions exist for this. } \\
\text { - Farming is represented only for crops that serve } \\
\text { as fodder, which means that valorization is done } \\
\text { through livestock breeding. } \\
\text { - Stock row is in decline, with only a few larger } \\
\text { farms in cattle breeding. } \\
\text { - Poultry is not significantly developed with } \\
\text { the arrival of Vindija. There is no cooperation } \\
\text { between Vindija and family farms. } \\
\text { - Insufficient activities in the domain of adding } \\
\text { value to agricultural products. }\end{array}$ \\
\hline OPPORTUNITIES & $\begin{array}{c}\text { THREATS } \\
\end{array}$ \\
\hline $\begin{array}{l}\text { - Transition in Serbia started in } 2000 \text {, when the } \\
\text { basic preconditions for its implementation } \\
\text { were acquired. Liberalization of trade relations } \\
\text { and capital balance enabled the integration of } \\
\text { Serbia's economic system into international } \\
\text { financial and commodity flows. } \\
\text { - Completion of market institutions, in particular } \\
\text { the development of financial markets, the } \\
\text { development of an efficient market for goods and } \\
\text { services, the construction of infrastructure, more } \\
\text { efficient state administration and the judiciary, } \\
\text { and the reduction of corruption - are necessary } \\
\text { preconditions for developing a stimulating } \\
\text { macroeconomic environment. }\end{array}$ & $\begin{array}{l}\text { - In the macroeconomic environment of Serbia } \\
\text { there are various gaps that can be eliminated } \\
\text { by a new approach that implies major } \\
\text { changes, which are aimed at establishing a } \\
\text { new relationship towards the macroeconomic } \\
\text { environment. } \\
\text { - Companies have long been doing their business } \\
\text { activities that characterized the inefficiency and } \\
\text { lack of motivation of employees. } \\
\text { - Inadequate economic development of } \\
\text { Serbia is determined by a number of factors, } \\
\text { among which the unfavorable structure of } \\
\text { the economy, the loss of traditional markets, } \\
\text { financial indiscipline, insufficient investment, } \\
\text { etc. are distinguished. }\end{array}$ \\
\hline
\end{tabular}

Source: Author's Research, 2016 
The pillars of the realization of the goal will be based on high investments in the construction of social, physical and economic infrastructure, while encouraging greater application of knowledge and innovation and respecting the principles of sustainable development and equal rights for all. Precondition for achieving the vision and strategic goal of the Municipality in the field of rural development - Is the realization of specific objectives, as well as measures and projects within the framework of the three selected development priorities (development directions). The three (3) defined development priorities essentially determine the way in which the strategic goal is to be realized, i.e. they are instruments of the strategic goal of the Municipality in the field of agriculture and rural development (Strategy for development of agriculture and rural development in Lajkovac 2011-2015): 1) Development priority: Strengthening the competitiveness of the agrarian sector in the domestic and foreign markets; 2) Development priority: Sustainable management of natural resources and environmental protection; 3) Development priority: Improving the quality of life of the rural population and the diversification of the rural economy

For each of the defined development priorities, realistic measures have to be identified in order to achieve development priorities and specific goals in priority directions within a specific time frame. Measures of the first development priority are the following (Strategy for development of agriculture and rural development in Lajkovac in period 2011 - 2015): 1) Education and advisory support to farmers; 2) Protection and preservation of agricultural land and improvement of agricultural infrastructure; 3) Supporting farmers to boost productivity and competitiveness of agricultural production; 4) Establishment, development and strengthening of farmers' association through forms: associations, cooperatives, clusters; 5) Development of new products with higher added value, with improvement of product quality and introduction of quality standards; 6) Promotion of the promotion and placement of agricultural food products; 7) Strengthening the institutional capacities of the municipal administration in the area of rural development and improving inter-institutional cooperation.

Measures of the second development priority (Strategy for development of agriculture and rural development of Lajkovac in the period 2011 - 2015): 1) Environmental situation analysis; 2) Reducing the negative impact on the Kolubara coal mine on the environmental quality of the Municipality and the Region; 3) Solid wastes management; 4) Management of waste and atmospheric waters; 5) Affirmation of renewable energy programs; 6) Increasing the area under the greenery; 7) Education of local actors and population in the field of environmental protection; 8) Environmental monitoring (continuous measurement of environmental parameters); 9) Networking of all stakeholders related to issues of environmental protection and improvement.

Finally, the measures of the third development priority (Development Strategy of the Agriculture and Rural Development of Lajkovac in the period 2011-2015): 1) Construction and improvement of physical and communal infrastructure in the villages; 2) Improving social infrastructure in villages and providing health and social protection; 3) Protection and preservation of cultural and historical heritage; 4) Change of the http://ea.bg.ac.rs 
rural economy towards the diversification of economic activities in the countryside; 5) Retention and return to young people to the village; 6) Promote LIDER's approach to rural development. Through the presented development priorities and measures, the guidelines on the future agricultural development of the municipality of Lajkovac are laid out on the basis of sustainability, whose realization would show that Lajkovac is a socially responsible community, which uses its potentials and resources, in order to provide better living conditions for all its inhabitants, according to the principles equality and justice.

\section{Conclusions}

The development of rural areas is closely linked to the development of agriculture and the processing of agricultural products, so the agricultural production is traditionally the most important sector of the rural economy and the main source of income for the rural population. Consequently, investments in the development of micro-enterprises in the field of processing of agricultural products are necessary, as well as raising the value of products by obtaining the designations of geographical origin. By investing in the mentioned activities, the competitiveness of agricultural holdings on the market would be improved, increasing the income of the farms would improve their economic position, which would enable better quality of life in rural areas and reduce the rate of depopulation of rural areas. Conditions that would contribute to the employment of the rural population are the strengthening of entrepreneurship and the development of micro-enterprises.

Based on the research results, the following conclusions can be drawn:

- The municipality of Lajkovac has favorable factor conditions for the development of agriculture. The favorable climatic factors, the diversity of the types of land, favorable hydrogeology and good road infrastructure are good conditions for the development of agricultural production, and above all, livestock, forestry and fruit growing;

- The municipality is dominated by small, non-specialized agricultural producers without clear business and market orientation. The result of such a production structure and poor governance are low and irregular income with the absence of serious planning, development and major investments;

- The municipality of Lajkovac has a significant tradition in livestock production, especially when it comes to cattle breeding;

- It will also be important to invest in plants for sorting, packaging and standardization of fruits and vegetables, as well as in the processes of implementation and certification of food safety and quality systems.

- With regard to the development of Lajkovac agriculture in the coming period, it will be important to develop the processing sector, that is, capacity building, especially in the MESP sector, in the field of processing meat, milk, fruit and vegetables. 
Vision of Agriculture implies the development of more propitious and more competitive agriculture composed of commercial and family farms dealing exclusively with agriculture and / or dealing with agriculture in terms of additional source of income. However, the desired future of this area will not be distorted by itself or because someone is eager to do so. The desired future and the achievement of the strategic goals of the Lajkovac municipality in the field of agriculture require immediate action. The future of the economic vitality of local communities to a lesser extent is the function of available resources and geographical position, and more strong leadership and effective strategy.

\section{Acknowledgements}

Paper is a part of research within the project no. III 46006 - Sustainable agriculture and rural development in the function of accomplishing strategic objectives of the Republic of Serbia in the Danube region, financed by the Ministry of Education, Science and Technological Development of the Republic of Serbia. Project period: 2011-2018.

\section{Conflict of interests}

The authors declare no conflict of interest.

\section{References}

1. Analysis of agriculture and food industry of Serbia in 2015, Association for Agriculture, Food Industry, Forestry and Water Management, Chamber of Commerce of Serbia (SCC), Belgrade, March 2016. [in Serbian: Analiza poljoprivrede i prehrambene industrije Srbije u 2015. godini, Udruženje za poljoprivredu, prehrambenu industriju, šumarstvo i vodoprivredu, Privredna komora Srbije (PKS), Beograd, mart 2016].

2. Dobson, A. (1996). Environment Sustainabilities: An Analysis and a Typology, Environmental Politics, 5(3), 401-428.

3. Đuričin, D. (2006). Transition, stabilization and sustainable development: Perspective of Serbia, Introductory paper. Miločer Economic Forum 2006: European Priorities and Regional Cooperation, Association of Economists of Serbia, Miločer. [in Serbian: Đuričin, D. (2006), Tranzicija, stabilizacija i održivi razvoj: Perspektiva Srbije].

4. Economic Accounts of Agriculture in the Republic of Serbia 2007-2014, Statistical Office of the Republic of Serbia, Belgrade, 2015. [in Serbian: Ekonomski računi poljoprivrede u Republici Srbiji 2007-2014, Republički zavod za statistiku, Beograd, 2015].

5. Elkington, J. (1998). Cannibals with forks: The triple bottom line of 21st century business, Gabriola Island, BC Canada: New Society Publishers. 
6. Report on Strategic Environmental Assessment, Detailed Regulation Plan, Industrial Zone 2, Lajkovac Municipality, 2014. [in Serbian: Izveštaj o strateškoj proceni uticaja na životnu sredinu, Plana detaljne regulacije, Industrijska zona 2, opština Lajkovac, 2014].

7. Report from the focus group meeting in the premises of the municipality of Lajkovac, Department of Economy and Property Legal Affairs, Lajkovac, July 12, 2016. [in Serbian: Izveštaj sa sastanka fokus grupe u prostorijama opštine Lajkovac, Odeljenje za privredu I imovinsko pravne poslove, Lajkovac, 12.07.2016].

8. Mihailović, B., Paraušić, V., Simonović, Z. (2007). Analysis of the business environment of Serbia in the final phase of economic transition, monograph, Institute of Agricultural Economics, Belgrade. [in Serbian: Mihailović, B., Paraušić, V., Simonović, Z. (2007). Analiza faktora poslovnog ambijenta Srbije u završnoj fazi ekonomske tranzicije]

9. Nikolić, R., Fedajev, A., Stefanović, V., Ilić, S. (2017). Agriculture Sector in the Western Balkan Countries during the Transition Period. Economics of Agriculture (64) 1, 293-306.

10. Agriculture Census 2012, Volume 1, Statistical Office of the Republic of Serbia, Belgrade, 2014. [in Serbian: Popis poljoprivrede 2012, Knjiga 1, Republički zavod za statistiku, Beograd, 2014].

11. Census of Population, Households and Dwellings in the Republic of Serbia, 2011, Economically Active Population Occupied by Activity, Age and Gender, by Municipalities / Towns, Statistical Office of the Republic of Serbia, Belgrade, 2011. [in Serbian: Popis stanovništva, domaćinstava i stanova u Republici Srbiji, 2011, Ekonomski aktivno stanovništvo koje obavlja zanimanje prema delatnosti, starosti i polu, po opštinama/gradovima, Republički zavod za statistiku, Beograd, 2011].

12. Program of support measures for implementation of agricultural policy and rural development policy for the municipality of Lajkovac in 2016, Lajkovac, 2016. [in Serbian: Program mera podrške za sprovođenje poljoprivredne politike $i$ politike ruralnog razvoja za opštinu Lajkovac u 2016. godini, Lajkovac, 2016].

13. Simonović, Z., Jelocnik, M.,Vasić, Z. (2012). Economic Position of Serbian Agriculture in the Period Transition, Economics of Agriculture, Belgrade, No. 3/2012, 535-544.

14. Statistical Yearbook of the Republic of Serbia, Statistical Office of the Republic of Serbia, Belgrade, 2015. [in Serbian: Statistički godišnjak Republike Srbije, Republički zavod za statistiku, Beograd, 2015]. 
15. Strategy for Local Sustainable Development of the Municipality of Lajkovac for the period 2015-2025, Municipality of Lajkovac, Valjevo, 2015. [in Serbian: Strategija lokalnog održivog razvoja opštine Lajkovac za period 2015-2025, opština Lajkovac, Valjevo, 2015].

16. Strategy for the Development of Agriculture and Rural Development of Lajkovac in the period 2011 - 2015, Institute for Agricultural Economics, Belgrade, July 2011. [in Serbian: Strategija razvoja poljoprivrede i ruralnog razvoja Lajkovca u periodu 2011. - 2015. godine, Institut za ekonomiku poljoprivrede, Beograd, jul 2011].

17. Vasiljević, Z., Zarić, V., Zakić, V. (2011). Basic strategic determinations of the development of agriculture and villages in Serbia until 2020, Ekonomski vidici, 2011, vol. 16, (2) 275-287. [in Serbian: Vasiljević, Z., Zarić, V., Zakić, V. (2011), Osnovna strateška opredeljenja razvoja poljoprivrede i sela u Srbiji do 2020. godine].

18. Vojinović, Ž., Zelenović, V., Cvijanović, D. (2017). State Support Program in Agriculture Crediting, Economics of Agriculture (64) 1, 339-358.

19. Permanent conference of cities and municipalities [in Serbian: Stalna konferencija gradova i opština] http://skgo.org/municipalities/16/privreda (July 13, 2016).

20. Vindija, http://www.vindija.hr (July 17, 2016).

21. Fruvela, http://www.fruvela.com (July 17, 2016).

22. Iva Agrar Lajkovac, www.iva-agrar.rs (July 17, 2016).

23. Microcontrollers, http://www.mikroe.com (July 17, 2016).

24. Borverk Lajkovac, https://borverk.ls.rs/rs (July 17, 2016). 
UDC 338.43:63

ISSN 0352-3462

ECONOMICS OF

AGRICULTURE

\section{CONTENT}

1. Branko Mihailović, Zoran Simonović, Miodrag Brzaković

STRATEGIC PLANNING OF SUSTAINABLE DEVELOPMENT

OF AGRICULTURE OF LAJKOVAC MUNICIPALITY. . . . . . . .475

2. Snežana Milošević Avdalović

IMPACT OF FIRM SPECIFIC FACTORS ON PROFITABILITY

OF INDUSTRIAL GRINDING COMPANIES. . . . . . . . . . . 493

3. Siniša Zarić, Igor Ilievski

THE NONMARKET ENVIRONMENT OF THE WINE INDUSTRY

IN THE REPUBLIC OF MACEDONIA: THE CASE OF WINES OF

MACEDONIA ASSOCIATION (FROM MARKET RIVALS TO

ALLIES IN THE NONMARKET ENVIRONMENT) $\ldots \ldots . \ldots$

4. Viktorija Petrov, Nada Trivić, Đorđe Čelić

\section{ASSESSING SUSTAINABILITY}

OF THE SOUTHEAST EUROPEAN ECONOMIES . . . . . . . . . 519

5. Mlađan Maksimović, Tatjana Janovac, Darjan Karabašević, Miodrag Brzaković

SOLUTION OF GENERAL AND PREVENTION OF ECOLOGICAL

PROBLEMS OF STARA PLANINA MOUNTAIN AS POTENTIAL

OBSTACLES TO THE DEVEOPMENT OF RURAL TOURISM . . . . . 531

6. Marija Paunović, Olivera Milutinović, Goran Puzić

PERSONAL SUBJECTIVITY IMPACT REDUCTION IN CHOICE

OF SOUR CHERRY VARIETIES FOR ORCHARD

ESTABLISHMENT USING FUZZY SYSTEM . . . . . . . . . . . 545

7. Snežana Urošević, Dragiša Stanujkić, Darjan Karabašević, Pavle Brzaković

USING SINGLE VALUED NEUTROSOPHIC SET TO SELECT

TOURISM DEVELOPMENT STRATEGIES IN EASTERN SERBIA . . 555

8. Rade Popović, Dalibor Panić

TECHNICAL EFFICIENCY OF SERBIAN DAIRY

PROCESSING INDUSTRY . . . . . . . . . . . . . . . . 569 
9. Marijana Joksimović, Biljana Grujić, Dušan Joksimović

CORRELATION AND REGRESSION ANALYSIS OF THE IMPACT

OF LEASING ON AGRICULTURAL PRODUCTION IN REPUBLIC

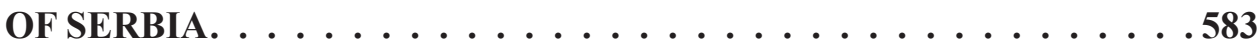

10. Boris Kuzman, Dajana Ercegovac, Mirela Momčilović

DEVELOPMENT OF DERIVATIVE TRADING ON FINANCIAL

MARKET AND AGRIBUSINESS SECTOR IN SERBIA. . . . . . . . 601

11. Goran Perić, Marko Gašić, Marija Stojilković, Ivana Nešić

THE IMPACT OF EMPLOYEE SATISFACTION ON THE TOURIST

SATISFACTION WITH THE SERVICES OF SPA TOURISM . . . . . 617

12. Nebojša Gvozdenović, Dejan Brcanov

VEHICLE SCHEDULING IN A HARVEST SEASON . . . . . . . . 633

13. Srđan Šapić, Srđan Furtula, Danijela Durkalić

PRESTIGE AND NATIONAL IDENTITY AS PREDICTORS

OF FOOD PRODUCTS PURCHASE . . . . . . . . . . . . 643

14. Sonja D. Radenković, Jelena Šaranović, Boban Stojanović, Zorana Kostić,

Bojan Jokić

APPLYING INTELLECTUAL CAPITAL IN IMPROVING

AGRI-INDUSTRY AT REPUBLIC OF SERBIA . . . . . . . . . . 659

15. Mersida Jandrić, Vladimir Zakić

APPRAISAL OF THE DAIRY CAPITAL VALUE ON

THE TERRITORY OF THE PESTER PLATEAU . . . . . . . . 673

16. Goran Milošević, Marija Vuković, Duško Jovanović

TAXATION OF FARMERS BY THE INCOME TAX IN SERBIA . 683

17. Milan Počuča, Ivan Joksić, Bojana Drašković

ENVIRONMENTAL PROTECTION IN THE LIGHT OF

DISCREPANCY BETWEEN THE NORMATIVE AND THE REALITY • . 697

18. Sonja Lučić

EU TRADEMARKS FOR WINE WHICH CONTAINS

INDICATIONS OF GEOGRAPHICAL ORIGIN . . . . . . . . . . 715

19. Dejan Đurić, Vladimir Mitrović, Dragana Đurić, Jelena Ristić

EU TRADEMARKS FOR WINE WHICH CONTAINS

INDICATIONS OF GEOGRAPHICAL ORIGIN . . . . . . . . . . 731

20. Miljan Leković, Drago Cvijanović, Milena Jakšić

FARMLAND REAL ESTATE INVESTMENT TRUSTS . . . . . . . . 745 
21. Aleksandra Vujko, Nataša Papić-Blagojević, Tamara Gajić APPLYING THE EXPONENTIAL SMOOTHING MODEL FOR FORECASTING TOURISTS' ARRIVALS EXAMPLE OF NOVI SAD, BELGRADE AND NIŠ . . . . . . . . . . 757

22. Svetlana Vukosav, Vuk Garača, Milan Bradić

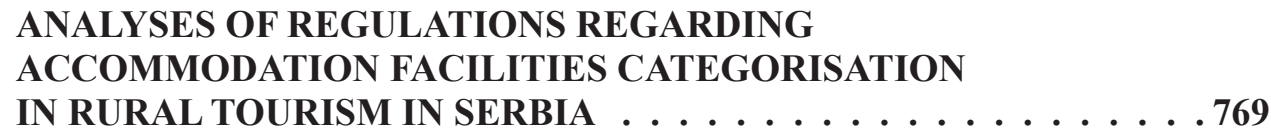

23. Mihajlo Munćan ECONOMIC EFFECTS OF IRRIGATION OF BASIC FIELD
CROPS ON FAMILY FARMS $\ldots \ldots \ldots \ldots \ldots 7 . \ldots \ldots 7$

24. Srećko Novaković, Dragan Vukasović, Bogdan Laban, Mladen Ivić, Vera Popović, Slobodan Popović

MANAGING AGRICULTURAL COMPANY BY USING INTERNAL CONTROL AND SIGNIFICANCE OF RISK PRESENTATION . . . . .801

25. Slobodan Nešković, Verica Savić

NATURAL RESOURCES PROTECTION STRATEGIES IMPORTANT FOR AGRICULTURE IN THE INTERNATIONAL COMMUNITY

AND REPUBLIC OF SERBIA . . . . . . . . . . . . . . 813

26. Goran Maričić, Sanja Škorić, Danijela Radenković APPLICATION OF THE PRINCIPLES OF CORPORATE GOVERNANCE IN AGRICULTURE COOPERATIVES . . . . . . . .827

27. Marija Kostić, Marija Lakićević, Snežana Milićević SUSTAINABLE TOURISM DEVELOPMENT OF MOUNTAIN TOURISM DESTINATIONS IN SERBIA . . . . . . . . . . . . 843

28. Radojko Lukić, Srđan Lalić, Azra Sućeska, Aida Hanić, Milica Bugarčić CARBON DIOXIDE EMISSIONS IN RETAIL FOOD . . . . . . . . . . 859 